\title{
Alterations of protein synthesis in the cyanobacterium Synechocystis sp. PCC 6803 after a salt shock
}

\author{
MaRTin Hagemann, ${ }^{1 *}$ LOTHAR WÖLFel ${ }^{2}$ and BuRKaRd KRÜGeR ${ }^{1}$ \\ ${ }^{1}$ Universität Rostock, Sektion Biologie, Doberaner Strasse 143, 2500 Rostock, GDR \\ ${ }^{2}$ Ernst-Moritz-Arndt-Universität, Sektion Biologie, Jahnstrasse 15, 2200 Greifswald, GDR
}

(Received 14 September 1989; revised 22 January 1990; accepted 13 February 1990)

\begin{abstract}
Salt-induced changes in protein synthesis were investigated in the cyanobacterium Synechocystis sp. PCC 6803. Immediately after a salt shock of $684 \mathrm{mM}-\mathrm{NaCl}$, total protein synthesis was almost completely blocked. Then, parallel to the accumulation of the osmoprotective compound glucosylglycerol, protein synthesis recovered gradually but remained diminished. The activation of glucosylglycerol synthesis was not inhibited by chloramphenicol at concentrations which totally inhibited protein synthesis. The qualitative protein composition of salt-shocked and control cells was similar. However, the rates of synthesis of single proteins were altered in cells shocked for $10 \mathrm{~h}$ and adapted to high salt conditions. Using two-dimensional gel electrophoresis, proteins were found which were synthesized at enhanced rates after adding salt.
\end{abstract}

\section{Introduction}

Cyanobacteria occur in a variety of environments, ranging from freshwater to hypersaline systems. Moreover, these organisms survive in environments which show dramatic changes in salinity. In the last 10 years the basic salt adaptation strategy of cyanobacteria has been elucidated. It includes, on the one hand, the avoidance of toxic internal amounts of inorganic ions using active export systems (Reed et al., 1985; Molitor et al., 1986) and, on the other hand, the synthesis and accumulation of osmoprotective compounds to achieve an equilibrium of osmotic potential. Three main salt-tolerance groups of cyanobacteria are distinguished according to the osmoprotective compounds accumulated. Cyanobacteria of the lowest salt tolerance synthesize sucrose and trehalose, cyanobacteria of an intermediate tolerance use glucosylglycerol and those of the highest salt tolerance accumulate glycine betaine and glutamate betaine (for a review see Reed et al., 1986).

Although the physiological processes involved in salt adaptation of cyanobacteria have been well studied, less work has been done with respect to their biochemistry. During the salt adaptation process changes in enzyme activities (Hagemann et al., 1989) and in ultrastructure (Schiewer \& Jonas, 1977) occur. Therefore, changes in the protein composition of cyanobacteria may also be involved in the process of salt adaption. Salt-induced protein synthesis has been demonstrated in Escherichia coli (hop operon; Clark \& Parker, 1984), in Bacillus subtilis (Hecker et al., 1988), in two Anabaena strains (Apte \& Bhagwat, 1989) and in higher plants (e.g. Hurkman \& Tanaka, 1988).

Using the unicellular cyanobacterium Synechocystis sp. PCC 6803, which accumulates glucosylglycerol after a salt shock (Reed \& Stewart, 1985), we investigated the effects of enhanced salt concentration on quantitative and qualitative changes in protein synthesis.

\section{Methods}

Organism and culture conditions. The axenic unicellular cyanobacterium Synechocystis sp. PCC 6803 was cultivated at $20 \mathrm{~W} \mathrm{~m}^{-2}$ (continuous light), $29^{\circ} \mathrm{C}$ and bubbling with $\mathrm{CO}_{2}$-enriched air $(5 \%, v / v)$ in basal medium containing $2 \mathrm{mM}-\mathrm{NaCl}$ (Allen \& Arnon, 1955). Exponentially growing Synechocystis cultures (about $8 \times 10^{7}$ cells $\mathrm{ml}^{-1}$ ) were sedimented by centrifugation $(1500 \mathrm{~g}, 5 \mathrm{~min})$ and suspended in the same volume of basal medium containing $684 \mathrm{mM}-\mathrm{NaCl}$ (salt shock). To obtain salt-adapted material Synechocystis was cultivated for $6 \mathrm{~d}$ in the $\mathrm{NaCl}$-containing medium. After the times indicated in the Figures samples were taken aseptically from the cultures and used in the labelling experiments. Cell number, cell volume and the content of glucosylglycerol were estimated as described by Hagemann et al. (1987).

Protein synthesis and methionine uptake rates. To determine the rates of total protein synthesis and methionine uptake, samples of cell suspension were pulse-labelled with $0.4 \mathrm{MBq} \mathrm{ml}^{-1} \mathrm{~L}-\left[{ }^{35}\right.$ S $]$ methionine (396 GBq mmol-1 ; Isocommerz, GDR) at $20 \mathrm{~W} \mathrm{~m}^{-2}$ and $29^{\circ} \mathrm{C}$. For estimation of methionine uptake the samples were filtered through $0 \cdot 2 \mu \mathrm{m}$ membrane filters (Sartorius) and immediately washed with 
$15 \mathrm{ml}$ of ice-cold medium of the same salt concentration. The total protein synthesis rate was determined according to Borbely $e t$ al. (1985). Radioactivity was measured by liquid scintillation counting

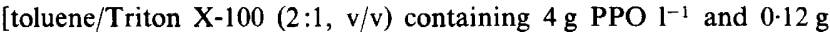
dimethyl POPOP ${ }^{-1}$ ]. To estimate the influence of chloramphenicol on total protein synthesis of Synechocystis the cells were pre-incubated with chloramphenicol of the desired concentration for $10 \mathrm{~min}$.

Electrophoresis. For the electrophoretic separation of proteins $10 \mathrm{ml}$ of cyanobacterial suspension was pulse-labelled for $20 \mathrm{~min}$ with $\left.0.8 \mathrm{MBq} \mathrm{L}-{ }^{35} \mathrm{~S}\right]$ methionine $\mathrm{ml}^{-1}$. After labelling the cells, chloramphenicol $\left(50 \mu \mathrm{g} \mathrm{ml}^{-1}\right)$ and L-methionine $\left(40 \mu \mathrm{g} \mathrm{ml}^{-1}\right)$ were added; the cells were then collected by centrifugation and deep frozen. For onedimensional separations the cells were disintegrated according to Hagemann et al. (1989) and the protein extract was concentrated using collodium bags (Sartorius). One-dimensional electrophoresis was done in polyacrylamide gels [stacking gel, $5 \%(\mathrm{w} / \mathrm{v})$; separating gel, $10 \%$ $(w / v)]$ in the discontinuous buffer system of Laemmli (1970). After fixing, the gels were stained with Coomassie brilliant blue R200, destained, dried and autoradiographed. For two-dimensional separation the cells were disrupted by ultrasonic treatment. The lysates were examined by the procedure of O'Farrell (1975). Fluorography and estimation of radioactivity of single protein spots were as described by Hecker et al. (1988). All experiments were repeated at least twice using independent cultures.

\section{Results and Discussion}

Effects of salt loading on the rates of protein synthesis, methionine uptake and on glucosylglycerol accumulation

Both total protein synthesis and methionine uptake by Synechocystis sp. PCC 6803 were markedly influenced by increasing the salt concentration in the cultivation medium. Immediately after salt shock protein synthesis was almost completely inhibited, whereas methionine uptake was only reduced by a factor of about two (Fig. 1A). In the two Anabaena strains investigated by Apte \& Bhagwat (1989), salt shock diminished methionine uptake and incorporation to about the same extent. Parallel to the synthesis of the osmoprotective substance glucosylglycerol (Fig. 1B), which was activated by the salt shock, total protein synthesis and methionine uptake recovered gradually. During the first $8 \mathrm{~h}$ after a salt shock of $684 \mathrm{~mm}-\mathrm{NaCl}$ a linear accumulation of glucosylglycerol occurred. Simultaneously, the protein synthesis rate reached about $50 \%$ of the value before the shock treatment and the rate of methionine uptake reached about $80 \%$ (Fig. 1A). In salt-adapted cells the glucosylglycerol content was further enhanced, but protein synthesis remained at about half of the rate in the control cells. During the first $10 \mathrm{~h}$ after salt shock, growth was completely inhibited. The growth rate of cells adapted to $684 \mathrm{~mm}-\mathrm{NaCl}$ was also diminished (not shown). This may be one reason for the reduced demand on protein synthesis. In contrast, the rate of methionine uptake reached the same level in both salt-adapted and control cells (Fig. 1A).
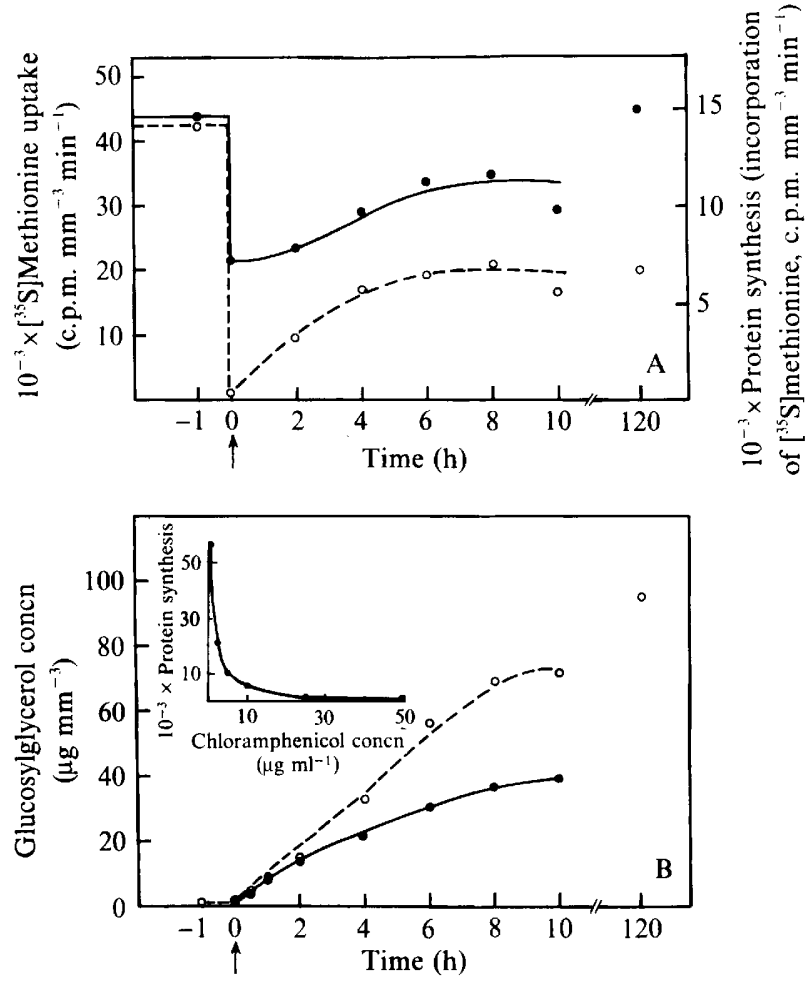

Fig. 1. A, Effect of a salt shock ( $684 \mathrm{mM}-\mathrm{NaCl}$; arrowed) on the rates of methionine uptake $(O)$ and protein synthesis $(O)$ in Synechocystis sp. PCC 6803 (pulse-labelled for $10 \mathrm{~min}$ ). Values at $120 \mathrm{~h}$ are for saltadapted cells. B, Effect of a salt shock (684 mM- NaCl; arrowed) on glucosylglycerol accumulation in the presence $(O)$ and in the absence (O) of chloramphenicol ( $50 \mu \mathrm{g} \mathrm{m}^{-1}$ final concentration) in Synechocystis sp. PCC 6803. Insert: effect of chloramphenicol on the rate of protein synthesis in control cells of Synechocystis sp. PCC 6803 determined by pulse-labelling with $\left[{ }^{35} \mathrm{~S}\right]$ methionine for $10 \mathrm{~min}$. Values in $\mathrm{A}$ and $\mathrm{B}$ are expressed per $\mathrm{mm}^{3}$ of cell volume.

The decrease in methionine uptake will automatically lower the measured rate of protein synthesis. However, the different extent to which these two processes were inhibited indicates that protein synthesis is directly inhibited. This may be caused by the massive influx of toxic inorganic ions (e.g. $\mathrm{Na}^{+}$and $\mathrm{Cl}^{-}$) immediately after salt shock as a consequence of a transient breakdown in plasmalemma semipermeability (Reed et al., 1985). Parallel to the accumulation of glucosylglycerol in cyanobacterial cells, these ions are actively extruded, so that a gradual recovery of protein synthesis becomes possible. Furthermore glucosylglycerol, as well as other osmoprotective compounds, may directly protect the protein synthesis machinery from the harmful effects of inorganic ions (Paleg et al., 1984; Warr et al., 1984).

Chloramphenicol $\left(50 \mu \mathrm{g} \mathrm{ml} \mathrm{m}^{-1}\right.$, Fig. 1B) completely inhibited protein synthesis whereas, within the first $2 \mathrm{~h}$, glucosylglycerol synthesis in salt-shocked Synechocystis cells was not affected by chloramphenicol (Fig. 1B). 
A

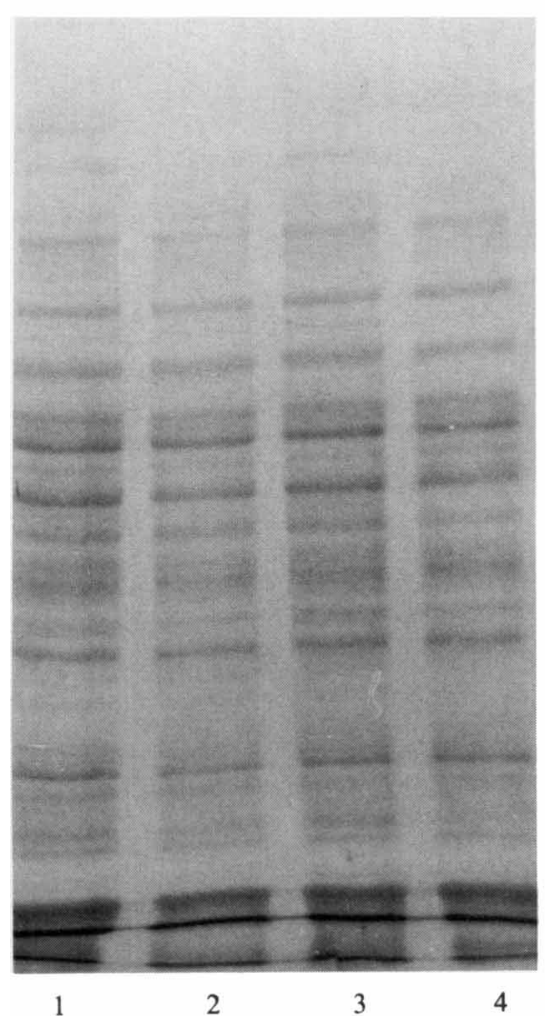

B

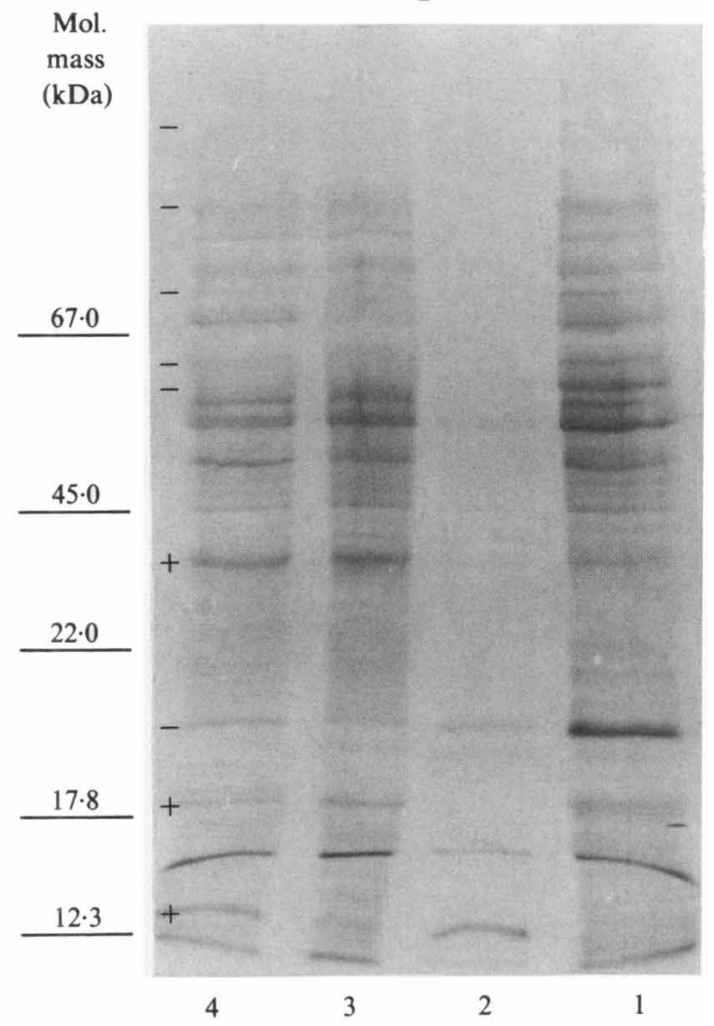

Fig. 2. Effect of a salt shock ( $684 \mathrm{mM}-\mathrm{NaCl})$ on polypeptide composition (A, Coomassie blue staining) and polypeptide synthesis (B, autoradiography) in Synechocystis sp. PCC 6803 analysed by one-dimensional SDS-PAGE. Track 1, 2 mM-NaCl, control;2, $10 \mathrm{~min}$, $684 \mathrm{mM}-\mathrm{NaCl} ; 3,10 \mathrm{~h}, 684 \mathrm{mM}-\mathrm{NaCl} ; 4$, adapted to $684 \mathrm{mM}-\mathrm{NaCl}$. Molecular mass markers are indicated. + , Increased protein synthesis rate; - , decreased protein synthesis rate.

Consequently, glucosylglycerol synthesis during the first $2 \mathrm{~h}$ after salt shock does not require de novo protein synthesis but results from the activation of inactive, preformed enzymes. The decrease in glucosylglycerol accumulation in chloramphenicol-treated cells starting about $2 \mathrm{~h}$ after the shock, in comparison to the control, may be evidence for a turnover of the glucosylglycerolsynthesizing enzyme system. On the other hand, nonspecific inhibition by chloramphenicol and its toxic light-induced metabolites (Sadka et al., 1989) cannot be excluded.

\section{Effects of salt shock on protein composition and protein synthesis patterns}

The protein composition of control cells grown in the basal medium was compared to that of cells immediately after salt shock, $10 \mathrm{~h}$ after salt shock (the time at which glucosylglycerol accumulation reached its first plateau), and of cells adapted to $684 \mathrm{mM}-\mathrm{NaCl}$. Using onedimensional denaturating PAGE and Coomassie blue staining we could not detect salt-induced alterations in the protein composition of Synechocystis sp. PCC 6803 (Fig. 2A).

To study the effect of a salt shock on the synthesis of single polypeptides, cells were pulse-labelled with $\mathrm{L}-\left[{ }^{35} \mathrm{~S}\right]$ methionine and the extracts were electrophoretically analysed. Immediately after a salt shock only a few bands of newly synthesized proteins could be detected (Fig. 2B). The sharp decrease in the total protein synthesis rate (see Fig. 1A) was therefore found for almost all of the synthesized proteins in the control cells. The greatly reduced methionine incorporation inevitably leads to the poorly labelled track 2 (Fig. 2B) and makes identification of any new proteins very difficult. The major polypeptides synthesized in control cells remained slightly visible in the salt-shocked cells and only a radioactively labelled band at about $13 \mathrm{kDa}$ appeared to increase following salt shock. In cells shocked for $10 \mathrm{~h}$, as well as cells adapted to $\mathrm{NaCl}$, the protein synthesis pattern again resembled that of control cells. No obvious newly induced protein bands could be detected, in contrast to the case of heat-shocked cyanobacteria (Borbely et al., 1985). Only three protein bands of about 


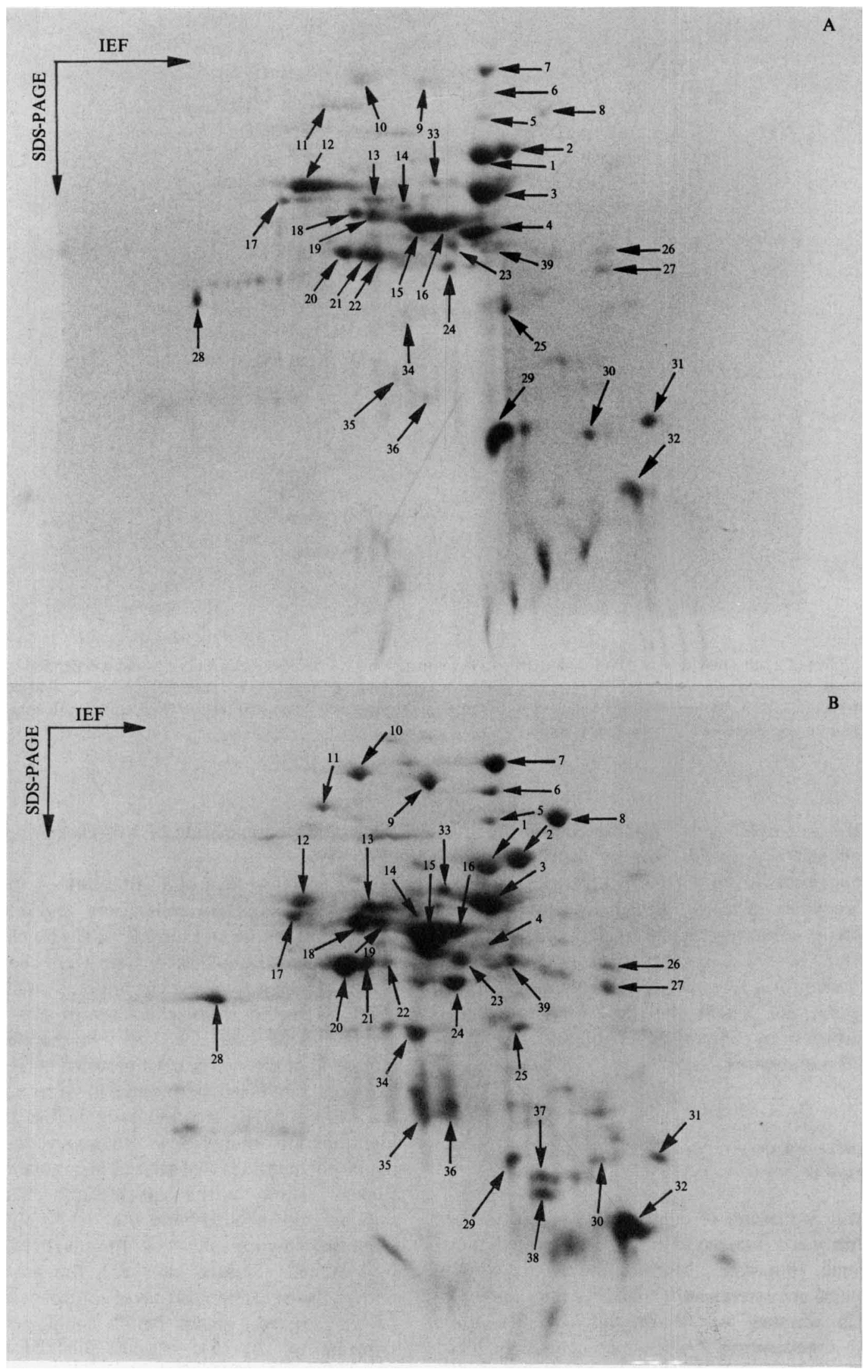




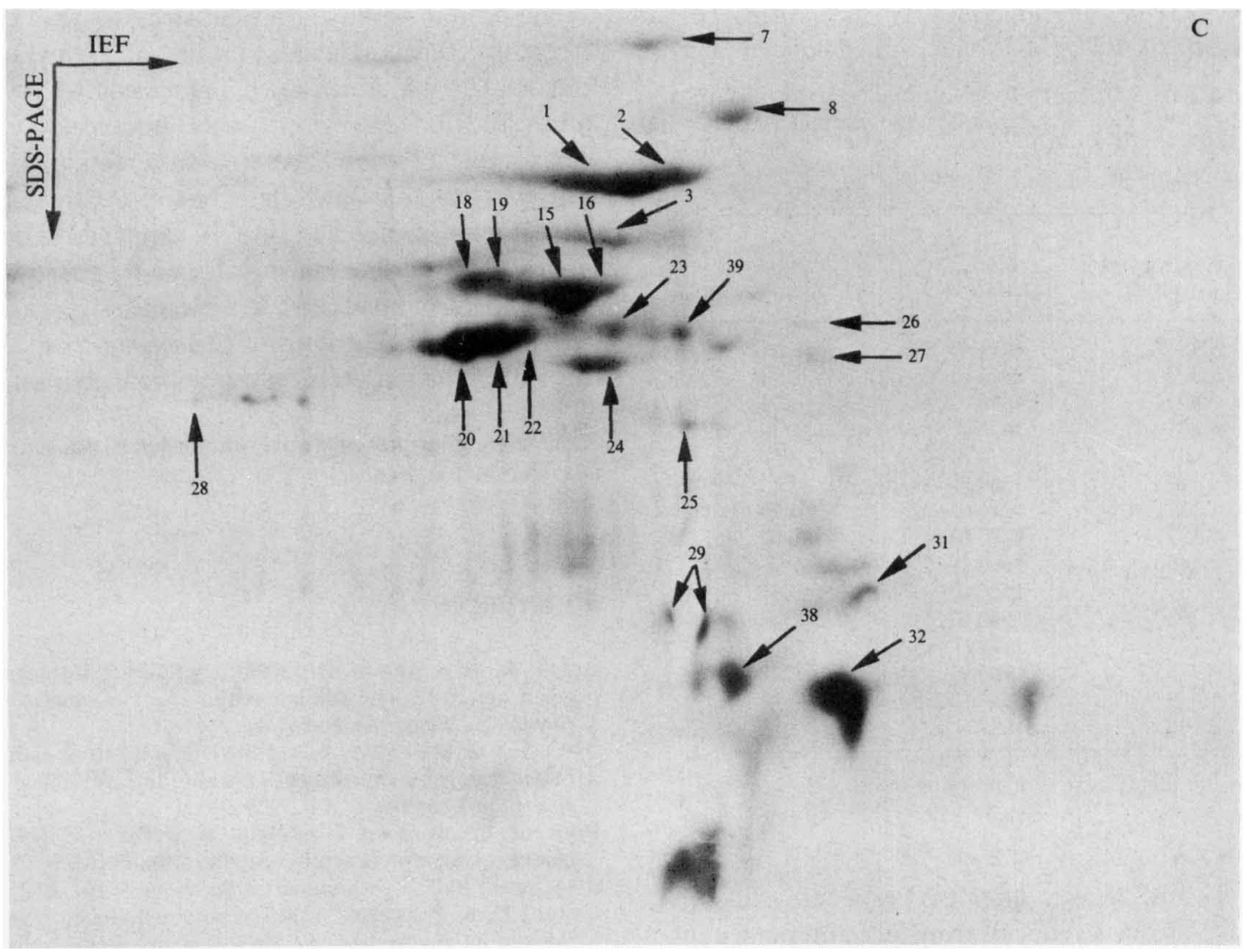

Fig. 3. Fluorograms of O'Farrell gels of ${ }^{35}$ S $]$ methionine-labelled proteins synthesized in Synechocystis sp. PCC 6803. A, $2 \mathrm{mM}-\mathrm{NaCl}$, control $\left(1.15 \times 10^{6}\right.$ c.p.m.); B, $10 \mathrm{~h}, 684 \mathrm{mM}-\mathrm{NaCl}\left(1.14 \times 10^{6}\right.$ c.p.m.); C, adapted to $684 \mathrm{mM}-\mathrm{NaCl}\left(1.56 \times 10^{6}\right.$ c.p.m.). (Values in parentheses are total radioactivity applied to the gels.) Many proteins are indicated by numbers to facilitate comparison. IEF, isoelectric focusing.

$32.4,16.6$ and $13 \mathrm{kDa}$ became more intensely labelled in the salt-shocked cells than in the control cells (Fig. 2B). However, Apte \& Bhagwat (1989) have found, in two Anabaena strains, several salt-stress-induced proteins by means of one-dimensional gel electrophoresis. On the other hand, the relative intensity of several protein bands was diminished in extracts of salt-loaded cells of Synechocystis sp. PCC 6803 (Fig. 2B), as was also found in Anabaena by Apte \& Bhagwat (1989). This is in good agreement with our quantitative measurements which demonstrated a reduction of total protein synthesis in these cells.

Each band obtained by one-dimensional PAGE may represent several proteins. Therefore, two-dimensional PAGE was used to obtain a more accurate insight into salt-induced alterations of the protein synthesis pattern in Synechocystis cells. Fluorography of proteins synthesized immediately after salt shock showed only a few faint spots at the positions of the main labelled proteins from control cells (not shown). In contrast, in cells shocked with $684 \mathrm{~mm}-\mathrm{NaCl}$ for longer times, several alterations were found as compared with control cells (Fig. 3). Three classes of proteins could be observed in Synechocystis: (a) proteins synthesized at about the same rate under salt-shock and non-salt conditions; $(b)$ proteins synthesized at a reduced rate under salt-shock conditions; and $(c)$ proteins synthesized at an enhanced rate under salt-shock conditions.

Examples of these three classes are shown in Table 1, where the radioactivity of spots is given for proteins, the positions of which could be clearly identified in all three separations. Especially interesting are proteins synthesized at an enhanced rate after salt shock, since these proteins may be involved in the process of salt adaptation. The synthesis of proteins $8,20,21,24,34,35$, 36 and 38 (numbers for identification of protein spots in Fig. 3) seems to be increased by salt shock (Table 1, Fig. 3 ). Since the positions of proteins 35,36 and 38 could not be determined exactly in the gel of the control cells no quantitative measurements of these spots were made. Whereas the synthesis of proteins $34,35,36$ was enhanced only during the adaptation phase, that of 
Table 1. Relative rates of synthesis of selected proteins of Synechocystis sp. PCC 6803 after NaCl treatment

Relative synthesis rates are given by the ratio of individual spot radioactivity per $10^{6}$ c.p.m. of total radioactivity applied to the gel. Values in parentheses are ratios of spot radioactivity between salt-loaded and control cells. ND, Not determined.

\begin{tabular}{|c|c|c|c|}
\hline $\begin{array}{l}\text { Spot* } \\
\text { number }\end{array}$ & $\begin{array}{c}\text { Control } \\
(2 \mathrm{mM}-\mathrm{NaCl})\end{array}$ & $\begin{array}{c}10 \mathrm{~h} \text { after } \\
\text { shock with } \\
684 \mathrm{~mm}-\mathrm{NaCl}\end{array}$ & $\begin{array}{l}\text { Adapted to } \\
684 \mathrm{~mm}-\mathrm{NaCl}\end{array}$ \\
\hline 1 & 4912 & $1511(0 \cdot 31)\}$ & \multirow{2}{*}{$7031(0 \cdot 87)$} \\
\hline 2 & 3174 & $2071(0.65)\}$ & \\
\hline 3 & 8954 & $4845(0 \cdot 54)$ & $2291(0 \cdot 26)$ \\
\hline 7 & 1459 & $1426(0.98)$ & $714(0.49)$ \\
\hline 8 & 670 & $1575(2 \cdot 40)$ & $1056(1 \cdot 60)$ \\
\hline 9 & 1198 & $1360(1 \cdot 14)$ & $223(0 \cdot 19)$ \\
\hline 10 & 1516 & $1216(0 \cdot 80)$ & $474(0 \cdot 31)$ \\
\hline $15 / 16$ & 11375 & $9775(0.86)$ & $6267(0.55)$ \\
\hline 20 & 2400 & $3399(1.42)$ & $4173(1 \cdot 74)$ \\
\hline 21 & 1617 & $1524(0.94)$ & $3341(2 \cdot 07)$ \\
\hline 22 & 2680 & $630(0.23)$ & $1354(0 \cdot 50)$ \\
\hline 24 & 1283 & $1924(1.50)$ & $1905(1 \cdot 48)$ \\
\hline 29 & 9765 & $1346(0 \cdot 14)$ & $1748(0 \cdot 18)$ \\
\hline 32 & 6796 & $8546(1 \cdot 26)$ & $9611(1 \cdot 41)$ \\
\hline 34 & 1005 & $1637(1.63)$ & ND \\
\hline
\end{tabular}

${ }^{*}$ For the identification of proteins see Fig. 3.

proteins 21,32 and 38 was increased especially in saltadapted cells. The occurrence of transient and persistent salt-stress-induced proteins was also found in Anabaena strains (Apte \& Bhagwat, 1989). Our relatively long pulse periods $(20 \mathrm{~min})$ may also have led to labelling of proteins that are only weakly synthesized, so that it is difficult to differentiate between newly induced proteins and proteins synthesized only at an enhanced rate.

In general, our observed protein-labelling pattern of Synechocystis sp. PCC 6803, obtained by two-dimensional gel electrophoresis, resembles that of Synechococcus sp. PCC 6301 as found by Borbely et al. (1985). The proteins induced by heat shock in Synechococcus sp. PCC 6301 (Borbely et al., 1985) are clearly at different positions from the proteins which were enhanced after salt shock in Synechocystis sp. PCC 6803. Most of the proteins whose synthesis increased on salt shock are of a relatively low molecular mass. They were found in regions of O'Farrell gels similar to proteins induced by salt stress in E. coli and B. subtilis (Clark \& Parker, 1984; Hecker et al., 1988). The nature of the single protein spots in our O'Farrell gels is unknown. Whether the proteins synthesized at enhanced rates are specifically involved in the process of salt adaptation, or whether they are only non-specific stress proteins, cannot be distinguished by our experiments. Apte \& Bhagwat (1989) discussed the participation of salt-stress-induced proteins in the salt adaptation of Anabaena, whereas in water-stressed Nostoc commune no novel class of proteins was found (Potts, 1986).
The proteins induced by salt stress are not engaged in the short term salt adaptation of Synechocystis sp. PCC 6803 (which involves glucosylglycerol accumulation and ion extrusion), since immediately after salt shock none of these proteins were found and protein synthesis was fully inhibited. Therefore, the biochemical activation of preformed proteins appears to be the main mechanism for short-term salt adaptation in cyanobacteria. The proteins found to be synthesized at enhanced rates in salt-shocked cells of Synechocystis sp. PCC 6803 may act in the long-term physiological adaptation phase.

The authors greatly appreciate the technical assistance of Mrs I. Dörr and Mrs K. Binder.

\section{References}

Allen, M. B. \& ARNon, D. I. (1955). Studies on nitrogen-fixing bluegreen algae. II. The sodium requirement of Anabaena cylindrica. Physiologia Plantarum 8, 653-660.

APTE, S. K. \& BHAGWAT, A. A. (1989). Salinity-stress-induced proteins in two nitrogen-fixing Anabaena strains differentially tolerant to salt. Journal of Bacteriology 171, 909-915.

Borbely, G., Suranyi, G., KorCZ, A. \& Palfi, Z. (1985). Effect of heat shock on protein synthesis in the cyanobacterium Synechococcus sp. strain PCC 6301. Journal of Bacteriology 161, 1125-1130.

Clark, D. \& Parker, J. (1984). Proteins induced by high osmotic pressure in Escherichia coli. FEMS Microbiology Letters 25, 81-83.

Hagemann, M., ERdmann, N. \& WitTenburG, E. (1987). Synthesis of glucosylglycerol in salt-stressed cells of the cyanobacterium Microcystis firma. Archives of Microbiology 148, 275-279.

Hagemann, M., Erdmann, N. \& Wittenburg, E. (1989). Studies concerning enzyme activities in salt-loaded cells of the cyanobacterium Microcystis firma. Biochemie und Physiologie der Pflanzen 184, $87-94$.

HeCKer, M., Heim, C., VölKer, U. \& WöLFEL, L. (1988). Induction of stress proteins by sodium chloride treatment in Bacillus subtilis. Archives of Microbiology 150, 564-566.

Hurkman, W. J. \& Tanaka, C. K. (1988). Polypeptide changes induced by salt stress, water deficit, and osmotic stress in barley roots: a comparison using two-dimensional gel electrophoresis. Electrophoresis 9, 781-788.

LAEMMLI, U. K. (1970). Cleavage of structural proteins during the assembly of the head of bacteriophage T4. Nature, London 227, 680685.

Molitor, V., Erber, W. \& PescheK, G. A. (1986). Increased levels of cytochrome oxidase and sodium-proton antiporter in the plasma membrane of Anacystis nidulans after growth in sodium-enriched media. FEBS Letters 204, 251-256.

O'FarRell, P. H. (1975). High resolution two-dimensional electrophoresis of proteins. Journal of Biological Chemistry 250, 4007-4021.

Paleg, L. G., Stewart, G. R. \& Bradbeer, J. W. (1984). Proline and glycine betaine influence protein solvation. Plant Physiology 75, 974 978.

PoTTs, M. (1986). The protein index of Nostoc commune UTEX 584 (cyanobacteria): changes induced in immobilized cells by water stress. Archives of Microbiology 146, 87-95.

ReED, R. H. \& STEWART, W. D. P. (1985). Osmotic adjustment and organic solute accumulation in unicellular cyanobacteria from freshwater and marine habitats. Marine Biology 88, $1-9$.

Reed, R. H., Richardson, D. L. \& Stewart, W. D. P. (1985). $\mathrm{Na}^{+}$ uptake and extrusion in the cyanobacterium Synechocystis PCC 6714 in response to hypersaline treatment. Evidence for transient changes in plasmalemma $\mathrm{Na}^{+}$permeability. Biochimica et Biophysica Acta 814, 347-355. 
Reed, R. H., Borowitzka, L. J., Mackay, M. A., Chudeck, J. A., Foster, R., WarR, S. R. C., Moore, D. J. \& Stewart, W. D. P. (1986). Organic solute accumulation in osmotically stressed cyanobacteria. FEMS Microbiology Reviews 39, 51-56.

SadKa, A., Lers, A., Zamir, A. \& AVRon, M. (1989). A critical examination of the role of de novo protein synthesis in the osmotic adaptation of the halotolerant alga Dunaliella. FEBS Letters 244, 9398.
SCHIEWER, U. \& JONAS, L. (1977). Die Wirkung unterschiedlicher $\mathrm{NaCl}-$ Konzentrationen auf die Ultrastruktur von Blaualgen. I. Microcystis firma. Archiv für Protistenkunde 119, 127-145.

WARr, S. R. C., ReED, R. H. \& STEWART, W. D. P. (1984). Osmotic adjustment of cyanobacteria: the effects of $\mathrm{NaCl}, \mathrm{KCl}$, sucrose and glycine betaine on glutamine synthetase activity in a marine and a halotolerant strain. Journal of General Microbiology 130, 2169-2175. 